\title{
PENERIMAAN KONSUMEN TERHADAP KERNAS NATUNA
}

\author{
Emil Samara $^{(1)}$, R. Marwita Sari Putri ${ }^{(2)}$, dan Made Suhandana ${ }^{(3)}$ \\ ${ }^{\text {(1) }}$ Mahasiswa Jurusan Teknologi Hasil Perikanan UMRAH \\ ${ }^{(2)(3)}$ Dosen Jurusan Teknologi Hasil Perikanan, Fakultas Ilmu Kelautan dan \\ Perikanan, Universitas Maritim Raja Ali Haji. Jalan Politeknik Senggarang, Kampus \\ UMRAH Senggarang Tanjungpinang, Kepulauan Riau, Hp +6281364548648
}

\section{emilsamara10@gmail.com}

\begin{abstract}
Abstrak
Kernas merupakan makanan khas natuna yang terbuat dari daging ikan tongkol (Thunnus tonggol) dan sagu butir dengan bahan tambahan seperti tepung maizena dan bumbu pelengkap lainnya. Penelitian ini mengenai tentang penerimaan konsumen terhadap kernas natuna, yang bertujuan untuk mengetahui tingkat penerimaan atau kesukaan konsumen terhadap kernas. Tahapan penelitian ini meliputi persiapan bahan baku dan bumbu, pengolahan dan uji organoleptik. Dari hasil penelitian uji tingkat kesukaan terhadap kernas dengan bahan tambahan tepung maizena tidak memiliki pengaruh yang nyata terhadap beberapa parameter uji organoleptik. Perlakuan terbaik berdasarkan hasil uji tengkat kesukaan terdapat pada perlakuan K2 ( maizena 2\%) dengan nilai rata-rata kenampakan 131.75, aroma 127.78, rasa 127.45 dan tekstur 123.38. Penutup hasil uji organoleptik berdasarkan tingkat kesukaan dari 80 panelis tidak terlatih.
\end{abstract}

Kata Kunci : Ikan tongkol (Thunnus tonggol), Kernas, Uji organoleptik

\section{PENDAHULUAN}

Kabupaten Natuna merupakan hasil pemekaran Kabupaten Kepulauan Riau sebelum menjadi Provinsi berdasarkan Undang-Undang No. 53 tahun 1999 dengan ibukota Ranai. Letak Kabupaten Natuna sangat srategis yang dilalui lalu lintas perdagangan internasional. Kabupaten Natuna terbagi ke dalam 12 kecamatan, yaitu Kecamatan Midai, Bunguran Barat, Bunguran Utara, Pulau Laut, Pulau Tiga, Bunguran Timur, Bunguran Tengah, Bunguran Selatan, Serasan, Subi, dan Serasan Timur (DKP Kabupaten Natuna 2015). Melimpahnya ikan yang terdapat di perairan Natuna terutama ikan tongkol menjadikan banyak olahan ikan yang terciptakan. Salah satu olahan atau makanan khas natuna yang belum banyak dikenal masyarakat luar yaitu kernas.

Kernas adalah makanan khas asli natuna yang dibuat sejak zaman 1960-an oleh masyarakat sekitarnya, mereka menjadikan makanan ini sebagai makanan pokok dan juga sebagai cemilan. Kernas ini terbuat dari campuran ikan tongkol dengan sagu lendang, dimana sagu lendang adalah butiran yang terbuat dari sagu yang diayak dan dibuat seperti bola-bola kecil. Kernas merupakan makanan favorit masyarakat natuna dari dahulu hingga sekarang, karena makanan ini dapat memberikan beberapa manfaat bagi yang mengkonsumsinya salah satu manfaat 
dari mengkonsumsi kernas ini yaitu dapat menunda lapar dan dapat sebagai lauk.

Banyaknya usaha kecil dan menengah (UKM) yang membuat olahan kernas dengan berbagai macam resep atau komposisi bahan, hampir setiap kecamatan yang terdapat di Natuna memiliki resep kernas sendiri. Sehingga perlu adanya resep atau fromulasi tetap untuk proses pengolahan kernas. Pada penelitian ini kernas menggunakan bahan tambahan yang sebenarnya tidak banyak digunakan oleh para pembuat kernas di Natuna yaitu Tepung maizena. Tidak adanya informasi mengenai tingkat kesukaan kernas dengan penambahan tepung maizena yang berbeda, maka penulis termotivasi untuk melakukan penelitian dengan judul "Penerimaan Konsumen terhadap Kernas Natuna".

Tujuan dari penelitian ini yaitu untuk mengetahui tingkat penerimaan konsumen terhadap kernas natuna berdasarkan uji organoleptik.

\section{METODE PENELITIAN}

\section{Bahan}

Bahan baku yang digunakan pada penelitian ini adalah daging ikan tongkol (Thunnus tonggol) yang didapatkan dari pasar bintan center, Tanjungpinang. Bahan-bahan tambahan yang digunakan antara lain tepung maizena, santan, bumbu masak, garam, lada hitam, lada putih, penyedap rasa dan minyak goreng.

\section{Alat}

Alat yang digunakan pada proses pembuatan kernas adalah timbangan digital, pisau, talenan, baskom dan blender. Sedangkan untuk uji organoleptik adalah score sheet, alat tulis, aqua gelas, piring dan kertas tisu.

\section{Formulasi Pembuatan Kernas}

Pembuatan kernas menggunakan bahan-bahan utama dan tambahan. Bahan utama kernas adalah ikan tongkol dan sagu sedangkan bahan tamabahn berupa tepung maizena dan bumbu dapur sebagai pemberi citarasa. Adapun formulasi dalam proses pembuatan kernas pada penelitian ini dapat dilihat pada Tabel 1 .

\section{Persiapan Bahan Baku dan Bumbu- bumbu}

\section{Kernas}

Ikan tongkol disiangi dan dicuci bersih setelah itu dilakukan pemfiletan dengan mengambil daging putih dan membuang daging hitam berserta tulang dan kepala. Kemudian daging ditimbang dengan berat $66 \%$, 64\% dan $62 \%$. Pada saat pengambilan daging diusahakan menggunakan es batu untuk menjaga gizi dari ikan tersebut. Daging yang sudat di fillet ditempatkan dibaskom untuk dilakukan pencucian daging. Kemudian daging yang sudah dicuci di blender. Ikan yang sudah di blender kemudian ditempatkan dibaskom dan ditutup menggunakan alumunium foil.

Bawang putih sebanyak 3\% kupas dan bersih, bawah merah sebanayk $6 \%$ kupas dan bersih dan cabe rawit sebanyak $1 \%$. Setelah itu bawang putih, bawang merah dan cabe rawit ditumbuk menggunakan lesung hingga halus dengan ditambahkan garam sebanyak $2 \%$.

\section{Pembuatan Kernas}

Daging yang sudah halus tadi dicampurkan dengan bumbu kemudian diaduk hingga rata. Selanjutnya masukkan santan kelapa sebanyak $4 \%$ kedalam masing-masing adonan aduk hingga rata, kemudian masukkan tepung 
maizena $0 \%, 2 \%$ dan $4 \%$ pada masing masing tempat aduk hingga rata setelah itu masukkan lada hitam, merica bubuk, dan penyedap rasa kedalam adonan. Terakhir masukkan tepung sagu (sagu butir) kedalam adonan aduk hingga rata. Setelah semua adonan tercampur rata selanjutnya cetak adonan dengan menggunakan tutup botol floridina yang sudah dibentuk dengan berat masingmasing cetakan yaitu $20 \mathrm{~g}$ kemudian digoreng.

\section{Parameter Penelitian}

\section{Uji Organoleptik (SNI 2006)}

Penentuan uji organoleptik (warna, rasa, aroma dan tekstur) dilakukan dengan uji kesukaan skala hedonik terhadap 80 panelis tidak terlatih. Adapun prosedur kerja cara pengujian adalah sebagai berikut :

1. Pemberian kode sampel setiap perlakuan menggunakan angka 3 digit menggunakan tabel random untuk memperkecil sifat subjektif.

2. Pembuatan formulir instruksi kerja (kuesioner) yang berisi petunjuk mencakup informasi, instruksi dan respon panelis.

a. Pada bagian informasi ditulis keterangan tentang nama panelis, tanggal pengujian, nama/jenis sampel yang diuji.

b. Pada bagian instruksi ditulis pemberian tugas dan cara-cara melakukan penilaian atau cara menyampaikan respon.

c. Pada bagian respon merupakan bagian yang harus diisi oleh panelis terhadap kesan kesukaan pada kernas yang disajikan yaitu : suka, netral, dan tidak suka.

d. Penyediaan peralatan untuk tempat kernas dan gelas untuk berkumur sebelum melakukan pengujian kernas dengan perlakuan berikutnya.

e. Mengubah data pengamatan dari skala hedonik menjadi skala numerik, yaitu suka $=3$, netral $=$ 2 , dan tidak suka $=1$.

f. Melakukan analisis satatistik.

\section{Analisis Data}

Data yang didapat dari uji organoleptik dianalisa dengan uji Kruskal-Wallis dengan menggunakan alat bantu computer progam SPSS versi 22, Apabila uji Kruskal-Wallis menunjukkan adanya perbedaan diantara perlakuan maka perlu dilakukan uji lanjut. Uji lanjut yang digunakan adalah uji Mann-Whitney untuk mengetahui perbedaan setiap variabel.

\section{Tabel 1. Formulasi Pembuatan Kernas}

\begin{tabular}{llll}
\hline \multirow{2}{*}{ Bahan } & Perlakuan & & \\
\cline { 2 - 4 } & K1 $(\boldsymbol{\%})$ & K2 $(\boldsymbol{\%})$ & K3 $(\boldsymbol{\%})$ \\
\hline Ikan Tongkol & 66 & 64 & 62 \\
Sagu Butir & 15 & 15 & 15 \\
Santan Kelapa & 4 & 4 & 4 \\
Tepung Maizena & 0 & 2 & 4 \\
Bumbu Pelengkap & 13 & 13 & 13 \\
Garam & 2 & 2 & 2 \\
\hline Total & 100 & 100 & 100 \\
\hline
\end{tabular}




\section{HASIL DAN PEMBAHASAN}

\section{Karakteristik Formulasi Kernas}

Pembuatan kernas menggunakan tiga formulasi dengan kosentrasi penambahan tepung maizena yang berbeda yaitu K1 0\%, K2 2\% dan K3 4\%. Penentuan formula terbaik ditentukan dengan menggunakan uji hedonik. Parameter yang diukur yaitu kenampakan, aroma, tekstur dalam keadaan mentah dan rasa dalam keadaan masak. Penilaian uji hedonik menggunakan skor 1 sampai 3 yaitu tidak suka, netral dan suka.

\section{Kenampakan}

Parameter penampakan merupakan salah satu faktor pertama yang dilihat konsumen dalam memilih makanan yang disajikan (Utiarahman et al. 2013). Penilaian kenampakan ini bertujuan untuk mengetahui penerimaan panelis yang dinilai dari kenampakan permukaan, keutuhan, kerapihan, dan warna kernas. Hasil uji kesukaan kernas terhadap kenampakan dapat dilihat pada Gambar 1.

Hasil penilaian rata-rata panelis terhadap kenampakan kernas berkisar antara 102,31 sampai 131,75 dengan range netral dan suka. Dapat dilihat pada Gambar 1 bahwa nilai rata-rata tertinggi yang disukai panelis untuk kenampakan terdapat pada perlakuan K2 (penambahan maizena 2\%) dengan nilai 131,75 , sedangkan nilai rata-rata terendah terdapat pada perlakuan K3 (penambahan maizena 4\%) dengan nilai 102,31 dan perlakuan K1 (penambahan maizena $0 \%$ ) dengan nilai 127,44 .

Perlakuan penambahan tepung maizena $0 \%$ dan $2 \%$ membuat kenampakan kernas tidak berbeda nyata sedangkan pada penambahan $4 \%$ membuat kenamapakan kernas berbeda nyata dengan kernas 0 dan $2 \%$. Hasil penelitian menunjukkan bahwa rerata kandungan kenamapakan kernas mengalami penurunan dari $2 \%$ ke $4 \%$. Hal ini sesuai dengan penelitian Wellyalina et al. (2013), menyatakan bahwa penambahan tepung maizena pada nugget tetelan merah tuna dapat menyebabkan penurunan nilai warna.

Berdasarkan uji kruskall wallis dengan uji lanjut mann-whitney yang dianalisis menggunakan SPSS versi 22 diketahui bahwa perbedaan komposisi tepung maizena yang ditambahkan dalam kernas memberikan pengaruh yang berbeda pada beberapa perlakuan, dimana perbedaan yang signifikan terdapat pada perlakuan (0\% dengan $4 \%$ ) dan (2\% dengan $4 \%)$ sedangkan ( $0 \%$ dan $2 \%$ ) tidak begitu berbeda. Nilai rata-rata kesukaan untuk kenampakan dimana nilai Asymp sig $<0.05$.

\section{Aroma}

Aroma merupakan sifat visual yang dapat digunakan untuk menilai kualitas dengan uji organoleptik menggunakan indera sensorik penciuman yang sensitif (Justisia et al. 2016). Hasil uji kesukaan kernas terhadap aroma dapat dilihat pada Gambar 2.

Hasil penilaian rata-rata panelis terhadap aroma kernas berkisar antara 107,61 sampai 127,78 dengan range netral hingga suka. Pada Gambar 2 tersebut dapat dilihat bahwa nilai ratarata tertinggi yang disukai panelis terhadap aroma terdapat pada perlakuan K2 (penambahan maizena 2\%) dengan nilai 127,78 sedangkan nilai rata-rata terendah terdapat pada perlakuan K3 (penambahan maizena 4\%) dengan nilai 107,61 dan perlakuan K1 (penambahan maizena $0 \%$ ) dengan nilai 126,12 . Dari hasil uji kesukaan dari ketiga perlakuan tidak memiliki perbedaan yang 
signifikan terhadap aroma yang dihasilkan.

Menurut penelitian Surawan (2007), menyatakan bahwa penambahan tepung maizena dengan jumlah penambahan $10 \%$, 30\% dan 50\% masih tidak memberikan pengaruh yang signifikan terhadap aroma fish nugget

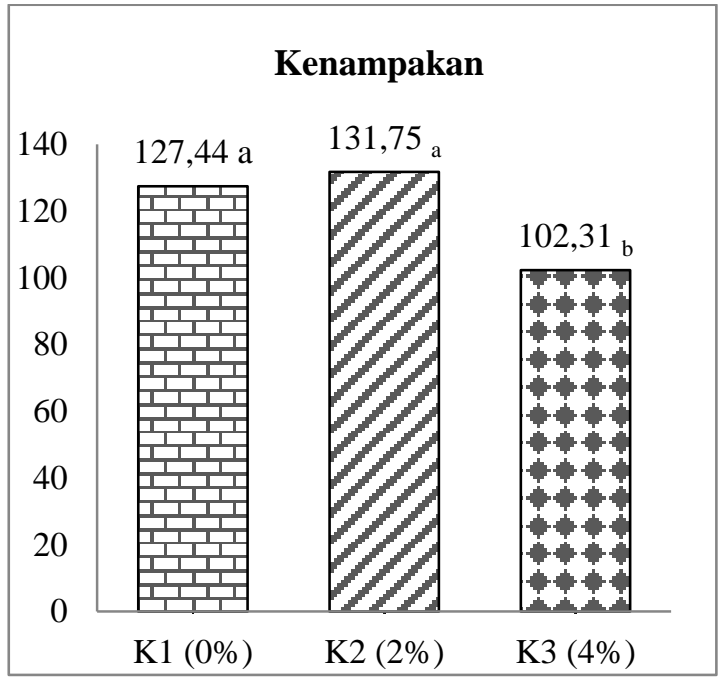

Gambar 1. Histogram nilai rata-rata kenampakan kernas

uji kruskall wallis dengan uji lanjut mann whitney yang dianalisis menggunakan SPSS versi 22 diketahui bahwa penambahan tepung maizena dengan konsentrasi $0 \%$ ke $2 \%$ tidak memberikan pengaruh terhadap aroma yang dihasilkan dimana nilai Asymp sig $>0.05$. Pada uji lanjut mann whitney yang memberikan pengaruh nyata hanya pada perlakuan $2 \%$ dengan $4 \%$ dimana nilai Asymp sig < 0.05 .

\section{Rasa}

Rasa merupakan faktor yang sangat penting dalam menentukan penerimaan atau penolakan seseorang dalam memilih bahan pangan atau makanan (Rahmawati et al. 2017). Hasil nilai rata-rata kesukaan panelis terhadap rasa dapat dilihat pada Gambar 3. ikan tuna. Ini berarti aroma fish nugget pada taraf penambahan tepung maizena $10 \%, 30 \%$ dan $50 \%$ tidak hanya dipengaruhi oleh jumlah daging ikan ataupun tepung yang digunakan, namun kemungkinan juga dipengaruhi bumbubumbu yang ditambahkan.

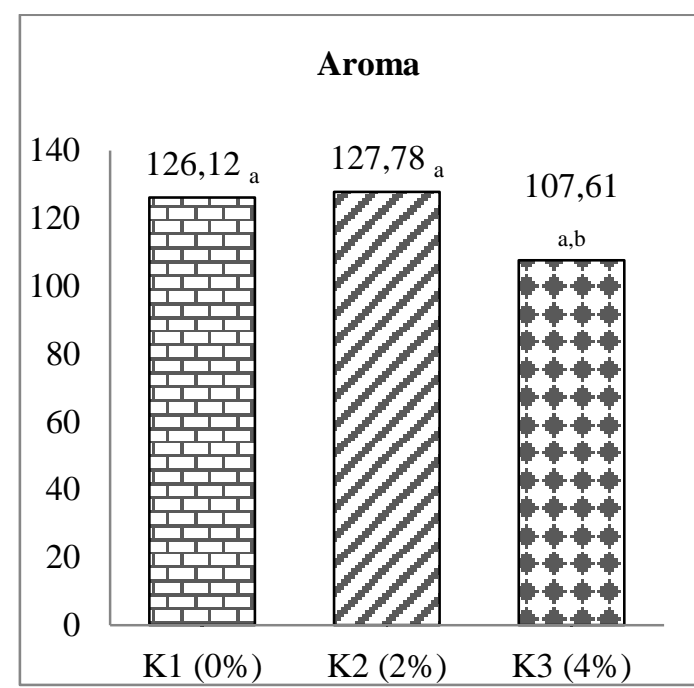

Gambar 2. Histogram nilai rata-rata aroma kernas

Hasil penilaian rata-rata panelis terhadap rasa kernas berkisar antara 115,66 sampai 127,45 dengan range netral hingga suka. Pada Gambar 3 dapat dilihat bahwa nilai rata-rata tertinggi yang disukai oleh panelis terdapat pada perlakuan K2 (penambahan maizena $2 \%$ ) dengan nilai 127,45 sedangkan nilai rata-rata terendah terdapat pada perlakuan K3 (penambahan maizena $4 \%$ ) dengan nilai 115,66 dan $\mathrm{K} 1$ (penambahan maizena 0\%) dengan nilai 118,39.

Penambahan tepung maizena tidak mempengaruhi rasa dari kernas, karena tepung maizena tidak memberikan rasa kepada kernas hanya saja semakin banyak tepung maizena yang ditambahkan kedalam adonan maka rasa yang akan dihasilkan semakin hambar dan sebaliknya semakin sedikit tepung 
maizena yang ditambakan maka rasa yang dihasilkan akan semakin kuat. Menurut Surawan (2007), juga menyatakan bahwa penambahan tepung maizena dengan jumlah penambahan $10 \% \quad 4,05 \%$ dan $50 \%$ masih tidak memberikan pengaruh yang signifikan terhadap rasa fish nugget ikan tuna. Ini berarti rasa fish nugget pada taraf penambahan tepung $10 \% 30 \%$ dan $50 \%$ tidak hanya dipengaruhi oleh jumlah daging ikan ataupun tepung yang

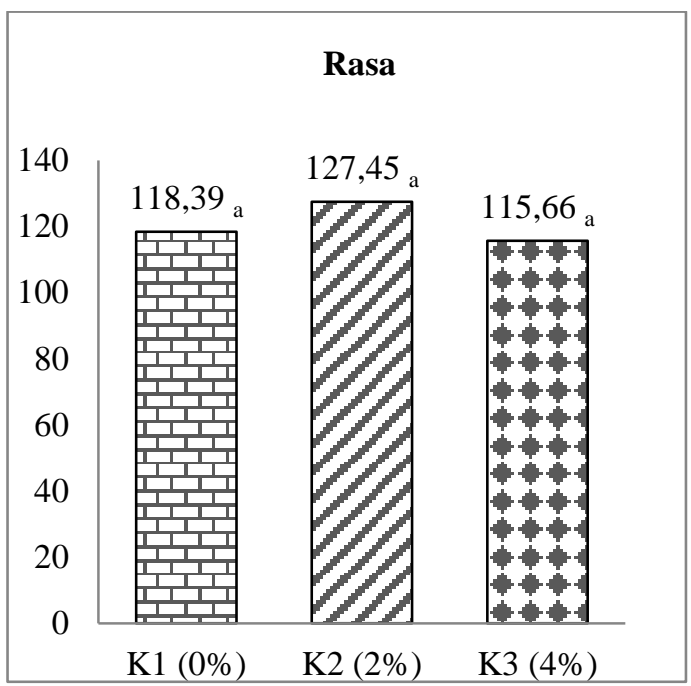

Gambar 3. Histogram nilai rata-rata rasa kernas

\section{Tekstur}

Tekstur merupakan salah satu faktor yang mempengaruhi pilihan konsumen terhadap suatu bahan pangan (Rohaya et al. 2013). Penilaian terhadap tekstur antara lain dengan cara menilai kehalusan dan kekenyalan terhadap produk yang dihasilkan dan merupakan salah satu parameter yang merupakan kombinasi dari keadaan fisik suatu makanan dan diindera oleh sentuhan penglihatan dan perabaan (Putra et al. 2015). Hasil nilai rata-rata kesukaan panelis terhadap tekstur dapat dilihat pada Gambar 4.

Hasil penilaian rata-rata panelis terhadap parameter tekstur berkisar digunakan, namun kemungkinan juga dipengaruhi rasa dari bumbu-bumbu yang ditambahkan.

Berdasarkan uji kruskall wallis dengan uji lanjut mann whitney yang dianalisis menggunakan SPSS versi 22 diketahui bahwa penambahan tepung maizena tidak memberikan pengaruh yang nyata terhadap rasa kernas yang dihasilkan dimana nilai Asymp sig > 0.05 .

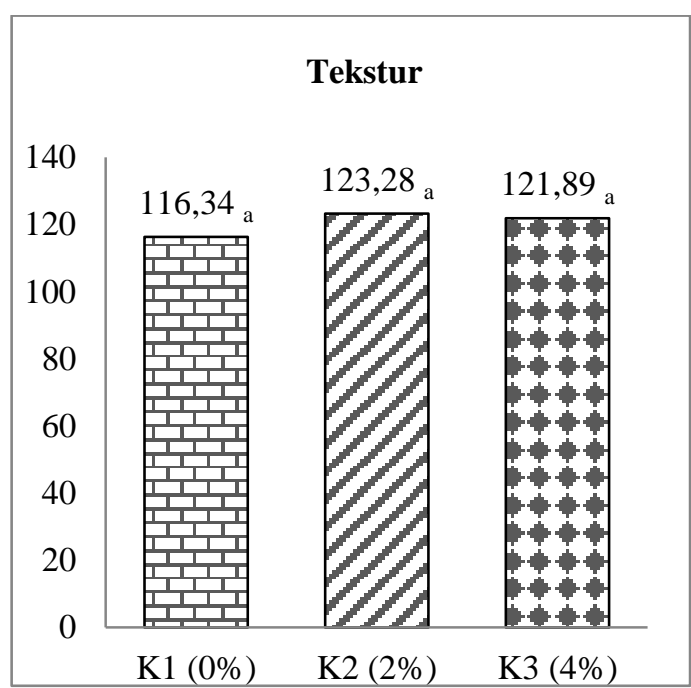

Gambar 4. Histogram nilai rata-rata tekstur kernas

antara 116,34 sampai 123,28 dengan range netral hingga suka. Pada histogram Gambar 4 dapat dilihat bahwa nilai ratarata tertinggi yang disukai panelis untuk tekstur terdapat pada perlakuan K2 (penambahan maizena 2\%) dengan nilai 123,28 sedangkan nilai rata-rata terendah yang disukai oleh panelis terdapat pada perlakuan K1 (penambahn maizena $0 \%$ dengan nilai 116,34 dan $\mathrm{K} 3$ penambahan maizena $4 \%$ ) dengan nilai 121,89 .

Penambahan tepung maizena pada kernas tidak memberikan perbedaan yang nyata terhadap tekstur yang dihasilkan hanya saja penelis memiliki kriteria yang berbeda sehingga pada 
penelitian ini penambahan tepung tidak terlalu mempengaruhi tekstur kernas yang dihasilkan. penelitian ini berbeda dengan penelitian Wellyalina et al. (2017), menyatakan bahwa adanya pengaruh dalam penambahan tepung maizena yang berbeda jumlahnya setiap perlakuan terhadap tekstur nugget tetelan merah tuna yang dihasilkan. Tekstur yang dihasilkan dari kernas dipengaruhi oleh bahan tambahan yang digunakan yaitu tepung maizena karena maizena berguna untuk membuat tekstur yang kompak dan kenyal. Salah satu tujuan digunakannya tepung maizena sebagai filler adalah untuk memperbaiki tekstur dan konsistensi yang kompak (Damayanti 2005).

Berdasarkan hasil uji kruskal wallis dengan uji lanjut mann whitney yang dianalisis menggunakan SPSS versi 22 diketahui bahwa penambahan tepung maizena tidak memberikan perbedaan yang nyata terhadap tekstur kernas yang dihasilkan dimana nilai Asymp sig >0.05.

\section{KESIMPULAN}

Berdasarkan hasil penelitian dapat disimpulkan bahwa kernas dengan perlakuan K2 (maizena 2\%) memiliki tingkat penerimaan tertinggi dari setiap paramater uji. Adapun penambahan tepung maizena dengan kosentrasi yang berbeda tidak mempengaruhi beberapa paramater uji seperti rasa, tekstur dan aroma sedangkan parameter kenampakan penambahan maizena memberikan pengaruh yang nyata antara kosentrasi $0 \%$ ke $4 \%$ dan $2 \%$ ke $4 \%$ dan tidak memberikan pengaruh nyata antara kosentrasi $2 \%$ dan $4 \%$.

\section{DAFTAR PUSTAKA}

BSN. 2006. SNI 01-2346-2006 Petunjuk pengujian organoleptik dan atau sensori. Badan Standarisasi Nasional.
Rohaya, S., Husna, N.E., Bariah, K. 2013. Penggunaan bahan pengisi terhadap mutu nugget vegetarian berbahan dasar tahu dan tempe. Jurnal Teknologi dan Industri Pertanian Indonesia, 5(1): 7-16.

Putra, D.A.P., Agustini, T.W., Wijayanti, I. 2015. Pengaruh penambahan karagenan sebagai stabilizer terhadap karakteristik otak-otak ikan kurisi (Nemipterus nematophorus). Jurnal Pengolahan dan Bioteknologi Hasil Perikanan, 4(2): 1-10.

Wellyalina., Azima, F., Aisman. 2013. Pengaruh perbandingan tetelan merah tuna dan tepung maizena terhadap mutu nugget. Jurnal Aplikasi Teknologi Pangan, 2(1): 917.

DKP. 2015. Statistik perikanan. Dinas Kelautan dan Perikanan. Kab. Natuna. Rahmawati, N., Budiyanto, A. 2017. Uji organoleptik nugget daging dada itik afkir dengan jenisdan dosis tepung yang berbeda. Jurnal Fillia Cedekia, 2(1) : 17-22.

Surawan, F.D.E. 2007. Penggunaan tepung terigu, tepung beras, tepung tapioka dan tepung maizena terhadap tekstur dan sifat sensoris fish nugget ikan tuna. Jurnal Sain Pertenakan Indonesia, 2(1): 78-84.

Utiarahman, G., Harmain, R.M., Yusuf, N. 2013. Karakteristik kimia dan organoleptik nugget ikan layang (Decapterus sp) yang disubtitusi dengan tepung ubi jalar putih (Ipomea batatas L). Jurnal Ilmiah Perikanan dan Kelautan 1(3):126138.

Justisia, W.A.H., Adi, A.C. 2016. Peningkatan daya terima dan kadar protein nugget substitusi ikan lele (Clarias batrachus) dan kacang merah (Vigna angularis). Jurnal Media Gizi Indonesia, 11(1): 106112. 